\title{
A Tentative Analysis of the Trophic Levels of North Sea Fish
}

\author{
Yang Jiming* \\ Ministry of Agriculture, Fisheries and Food, Directorate of Fisheries Research, Fisheries Laboratory, Lowestoit Suffolk \\ NR33 OHT, England
}

\begin{abstract}
Trophic levels of basic food items, feeding habits and trophic levels of various North Sea fishes have been derived from historical references and the MAFF North Sea Groundfish Survey data in 1977, 1978 and 1980. There is an obvious progression in the mean trophic levels from planktophagic (3.5) to benthophagic (3.9) and ichthyophagic (4.5). The mean trophic level of 34 species for the period 1947-77 is 3.67 . While the total catch and the catch of some species were fluctuating widely, the mean trophic level of the nominal catch of fish (excluding several less important species) showed almost no changes (3.62-3.76) from 1947 to 1977. Generally speaking, the catch should approximately reflect the abundance in a well exploited sea. Assuming that the trophic levels of 34 species were similar during 1947-77, fishing does not appear to have upset the fundamental ecological balance of the North Sea. In other words, the influence of fishing has not yet surpassed the self-regulatory capacity of the North Sea ecosystem.
\end{abstract}

\section{INTRODUCTION}

The trophic level of fish can be described in relation to their level of productivity and food consumption, and forms an important part of the structure of food webs in an ecosystem. The study of the trophic levels of fishes is of practical and theoretical significance.

The present work attempts to make an analysis of trophic levels of North Sea fishes using the many studies of their dietary habits that have been conducted since the last century.

\section{DATA SOURCES AND METHOD}

The trophic levels of basic food items of North Sea fishes as shown in Table 1 are derived from the literature. Following the usual practice the trophic level of algae is taken as 1 . Similarly, the trophic level of pure

- Permanent address: Institute of Oceanology, Academia Sinica, 7 Nan-Hai Road, Tsingtao, The People's Republic of China

Following modern Chinese custom, the author's family name is printed before the given name. The correct text citation of this paper would therefore be Yang (1982) and in a bibliography the reference would be to Yang, Jiming, 1982 herbivorous animals is equal to 2 , and those of the first, second and third carnivores are 3, 4 and 5, respectively. In fact most marine animals feed on more or less mixed diets, so that their mean trophic levels will not be exactly whole integers. For example, Temora longicornis is recorded as a mixed diet feeder. It feeds chiefly on diatoms and copepods, the proportion of diatoms in its stomach contents being slightly more than that of copepods (Lebour, 1922), and therefore the trophic level of $T$. longicornis is taken as 2.4 on a point basis. The trophic levels of the other animals are estimated on a similar basis (Table 1 ).

The feeding habits (based on food composition) of various fishes in the North Sea are derived from the literature on fish food studies (Smith, 1889, 1890; Scott, 1902; Todd, 1905, 1907; Bullen, 1912; Lebour, 1918. 1919; Hardy, 1924; Savage, 1937; Hartley, 1940; Rae, 1956, 1963, 1967; Raitt and Adams, 1962; Ryland, 1964; Macer, 1966, 1977; Zilanov, 1966, 1968; Braber and de Groot, 1973; Daan, 1973; Wyatt, 1974; Shuvaev, 1977; Last, 1978a, b, 1980), and in addition unpublished stomach contents data (about 7,000 fish) were made available to the author from the MAFF North Sea Groundfish Survey during 1977, 1978 and 1980. All the above data were reanalysed by the Points Method (Hynes, 1950) and ignored unimportant food items. 
Table 1. Trophic level of basic food items of North Sea fishes (based on the sources indicated)

\begin{tabular}{|c|c|c|}
\hline Food item & Trophic level & Sources \\
\hline Calanus finmarchicus & 2.3 & Lebour (1922), Raymont (1963), Marshall \& Orr (1972) \\
\hline Paracalanus parvus & 2.1 & Lebour (1922), Raymont (1963) \\
\hline Pseudocalanus elongatus & 2.1 & Lebour (1922), Raymont (1963) \\
\hline Pseudocalanus minutus & 2.1 & \\
\hline Temora longicornis & 2.4 & Lebour (1922), Raymont (1963) \\
\hline Eurytemora spp. & 2.4 & Kaestner (1967) \\
\hline Metridia Iucens & 2.1 & Raymont (1963) \\
\hline Centropages & 2.4 & Lebour (1922) \\
\hline Acartia clausii & 2.1 & Lebour (1922) \\
\hline Oithona similis & 2.1 & Lebour (1922) \\
\hline Oithona helgolandicus & 2.1 & \\
\hline Copepoda nauplij & 2.1 & \\
\hline Balanus nauplii & 2.1 & Raymont (1963) \\
\hline Cladocera & 2.1 & Raymont (1963) \\
\hline Thysanoessa inermis & 2.4 & Raymont (1963) \\
\hline Nyctiphanes couchii & 2.3 & Lebour (1922) \\
\hline Hyperiidae & 3.0 & Lebour (1922), Kaestner (1967) \\
\hline Mysids & 2.4 & Raymont (1963) \\
\hline Decapods larvae & 2.5 & Lebour (1922) \\
\hline Crangon & 3.2 & Allen (1960), Kaestner (1970), Tiews (1970) \\
\hline Eupagurus (= Pagurus) & 2.6 & Kaestner $(1970)$ \\
\hline Pandalus & 3.2 & Simpson (1970), Kaestner (1970) \\
\hline Portunus & 3.3 & Kaestner $(1970)$ \\
\hline Nephrops & 3.3 & Oakley (1978) \\
\hline Hyas & 3.3 & Kaestner $(1970)$ \\
\hline Appendicularia & 2.1 & Davis (1955) \\
\hline Nereis & 2.4 & Kaestner (1967) \\
\hline Pectinaria & 2.3 & Kaestner (1967) \\
\hline Terebella & 2.3 & Kaestner (1967) \\
\hline Sabella & 2.1 & Kaestner (1967) \\
\hline Polychaeta larvae & 2.1 & Lebour (1922) \\
\hline Scrobicularia & 2.1 & Kaestner (1967) \\
\hline Solen & 2.1 & Kaestner (1967) \\
\hline Tellina & 2.1 & Kaestner (1967) \\
\hline Lamellibranch larvae & 2.1 & Raymont (1963) \\
\hline Ophiura & 3.0 & Campbell (1976) \\
\hline Ophiothrix & 3.0 & Campbell (1976) \\
\hline Sagitta & 3.5 & Lebour (1922), Lebour (1924) \\
\hline Detritus feeders & 2.1 & Steele $(1974)$ \\
\hline
\end{tabular}

The values of the trophic levels of various fish were then calculated from those of the basic food items (Table 1) and the food composition of the fish.

An example of the calculation of the trophic level of a fish (the herring) is given in Table 2. The principal and secondary food items of the herring are derived from Savage (1937), unimportant items being ignored. Points are allocated to each food item according to its relative importance in the stomach contents of the fish (Column I). The trophic level of each food item, taken from Table 1, is entered in Column III. The relative contribution of each food item (Column IV) is the product of Columns II and III, divided by 100. The sum of the individual values in Column IV is the weighted mean trophic level of the food $(=2.450)$; that of the fish is obtained by adding 1 to this value to represent the fish itself, giving 3.450 or about 3.5 .
The mean trophic level of the nominal catch in the North Sea (Table 4, Fig. 1) is computed from 34 of the species listed in the ICES 'Bulletin Statistique' for the years 1947-77 (ICES, 1951-81), long rough dab, poor cod and bib were excluded because there are no catch data for these species; tunas, garfish, seabream, ratfish and unsorted and unidentified teleost fishes were also excluded because they contributed altogether less than $1 \%$ to the total catch of fish in 1968-77.

The accuracy of the values in Table 3 will clearly be influenced by the fact that many different methods have been used by individual authors to analyse the food contents of animals, and the Points Method of Hynes (1950) is itself not a precise one.

The percentages of herring and other plankton-feeding fishes in the nominal total catch of fish from the North Sea in the period $1947-77$ are computed from 
Table 2. Calculation of weighted mean trophic level of the food of herring

\begin{tabular}{|lcccc|}
\hline Food itern & $\begin{array}{c}\text { I } \\
\text { Points given }\end{array}$ & $\begin{array}{c}\text { II } \\
\text { of total } \\
\text { points }\end{array}$ & $\begin{array}{c}\text { III } \\
\text { Trophic level of } \\
\text { basic food item }\end{array}$ & $\begin{array}{c}\text { IV } \\
\text { Vlue of trophic level } \\
\text { (III } \times \text { II } \div \text { 100) }\end{array}$ \\
\hline Calanus finmarchicus & & 27 & 2.3 & 0.621 \\
Paracalanus parvus & 27 & 2 & 2.1 & 0.042 \\
Pseudocalanus elongatus & 2 & 1 & 2.1 & 0.021 \\
Temora longicornis & 1 & 9 & 2.4 & 0.216 \\
Metridia lucens & 9 & 1 & 2.1 & 0.021 \\
Centropages & 1 & 1 & 2.4 & 0.024 \\
Other copepods & 1 & 1 & 2.6 & 0.026 \\
Thysanoessa inermis & 1 & 3 & 2.4 & 0.072 \\
Nyctiphanes couchii & 3 & 9 & 2.3 & 0.207 \\
Meganyctiphanes & 9 & 3 & 3.0 & 0.072 \\
Hyperiidae & 3 & 8 & 2.5 & 0.240 \\
Decapoda larvae & 8 & 1 & 3.2 & 0.025 \\
Ammodytes larvae & 1 & 6 & 3.5 & 0.192 \\
Other fish larvae & 6 & 1 & 3.5 & 0.035 \\
Sagitta & 1 & 3 & 2.1 & 0.105 \\
Oikopleura & 3 & 21 & 3.0 & 0.441 \\
Other arganisms & 21 & 3 & & 0.090 \\
\hline Total & 3 & 100 & & 2.450 \\
\hline
\end{tabular}

Table 3. Feeding habits and trophic levels of various North Sea fishes

\begin{tabular}{|c|c|c|c|}
\hline Fish species & & Feeding habit & Trophic level \\
\hline Sprat & Sprattus sprattus & Planktophagic & 3.3 \\
\hline Raitt's sandeel & Ammodytes marinus & Planktophagic & 3.3 \\
\hline Norway pout & Trisopterus esmarkii & Planktophagic & 3.4 \\
\hline Herring & Clupea harengus & Planktophagic & 3.5 \\
\hline Scad & Trachurus trachurus & Planktophagic & 3.5 \\
\hline Mackerel & Scomber scombrus & Planktophagic & 3.5 \\
\hline Greater sandeel & Hyperoplus lanceolatus & Planktophagic & 3.5 \\
\hline Blue whiting & Micromesistius poutassou & Planktophagic & 3.7 \\
\hline Witch & Glyptocephalus cynoglossus & Benthophagic & 3.7 \\
\hline Plaice & Pleuronectes platessa & Benthophagic & 3.7 \\
\hline Sole & Solea solea & Benthophagic & 3.7 \\
\hline Lemon sole & Microstomus kitt & Benthophagic & 3.7 \\
\hline Flounder & Platichthys flesus & Benthophagic & 3.8 \\
\hline Dab & Limanda limanda & Benthophagic & 3.7 \\
\hline Grey gurnard & Eutrigla gurnardus & Benthophagic & 3.8 \\
\hline Long rough dab & Hippoglossoides platessoides & Benthophagic & 4.0 \\
\hline Haddock & Melanogrammus aeglefinus & Benthophagic & 3.9 \\
\hline Tub gurnard & Trigla lucerna & Benthophagic & 4,0 \\
\hline Catfish & Anarhichas lupus & Benthophagic & 4.0 \\
\hline Starry ray & Raja radiata & Benthophagic & 4.1 \\
\hline Poor cod & Trisopterus minutus & Benthophagic & 4.0 \\
\hline Bib & Trisopterus luscus & Benthophagic & 4.2 \\
\hline Red gurnard & Aspitrigla cuculus & Benthophagic & 4.1 \\
\hline Roker & Raja clavata & Benthophagic & 4.0 \\
\hline Pollack & Pollachius pollachius & Ichthyophagic & 4.4 \\
\hline Cod & Gadus morhua & Ichthyophagic & 4.4 \\
\hline Whiting & Merlangius merlangus & Ichthyophagic & 4.3 \\
\hline Halibut & Hippoglossus hippoglossus & Ichthyophagic & 4.4 \\
\hline Spurdog & Squalus acanthias & Ichthyophagic & 4.4 \\
\hline Skate & Raja batis & Ichthyophagic & 4.6 \\
\hline Saithe & Pollachius virens & Ichthyophagic & 4.5 \\
\hline Megrim & Leipidorhombus whiffiagonis & Ichthyophagic & 4.5 \\
\hline Hake & Merluccius merluccius & Ichthyophagic & 4.6 \\
\hline Turbot & Scophthalmus maximus & Ichthyophagic & 4.6 \\
\hline Brill & Scophthalmus rhombus & Ichthyophagic & 4.7 \\
\hline Ling & Molva molva & Ichthyophagic & 4.8 \\
\hline Angler & Luphius piscatorius & Ichthyophagic & 4.8 \\
\hline
\end{tabular}




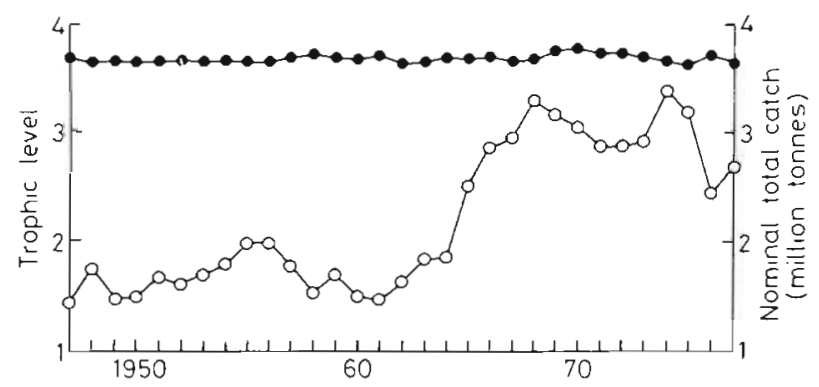

Fig. 1. Mean trophic level of nominal catch (filled circles) and nominal total catch (open circles) of North Sea fish during $1947-77$

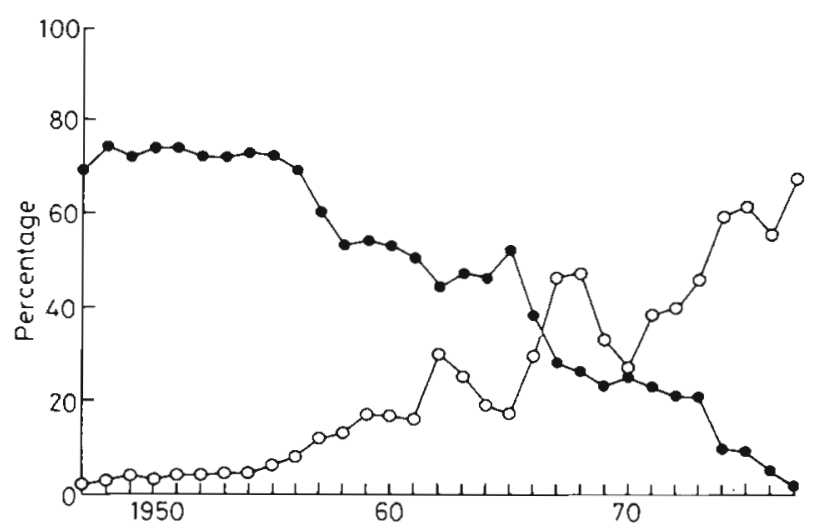

Fig. 2. Percentage of herring (filled circles) and of other plankton feeding fishes (open circles) in the nominal total catch of fish from the North Sea during 1947-77

ICES 'Bulletin Statistique' (ICES, 1951-81), again excluding the same less important fishes as mentioned above.

\section{RESULTS}

\section{Feeding Habit and Trophic Level of Various Fishes}

As may be seen from Table 3 , the feeding habits of 8 species - sprat, Raitt's sandeel, Norway pout, herring, scad, mackerel, greater sandeel and blue whiting - are planktophagic with a mean trophic level of 3.5 (range 3.3 to 3.7 ). The feeding habits of 16 species such as witch, plaice, sole, dab, grey gurnard, haddock, starry ray, poor cod and bib are benthophagic, with a mean trophic level of 3.9 (range 3.7 to 4.2). The feeding habits of 13 other species, whiting, cod, spurdog, skate, saithe, hake, brill, angler and so on, are ichthyophagic, with a mean trophic level of 4.5 (range 4.3 to 4.8 ). There is an obvious progression in the mean trophic levels from planktophagic (3.5) to benthophagic (3.9) and ichthyophagic (4.5). The overall mean trophic level of fishes for the period 1947-77 is 3.67 (Table 4).

\section{Long-Term Changes of Mean Trophic Level of Nominal Catch of Fish}

As shown in Table 4 and Fig. 1, the mean trophic level of nominal catches of North Sea fish during 1947-77 ranged from 3.62-3.76, showing almost no change during this period.

\section{DISCUSSION}

Since 1947 the total catch of fish excluding several less important species (see section 'Data Sources and Method') from the North Sea has fluctuated widely. During the period 1947-60 the total catch of fish was 1.43 to 1.97 million tonnes. From 1961 to 1968 there was a sharp increase to 3.28 million tonnes, and thereafter the level of catches has varied between 2.44 and 3.38 million tonnes.

For many individual species, the fluctuations of catch are even more evident than that of the total. The best known example is the herring, catches of which reached a peak level of 1.3 million tonnes in 1965 , followed by a sharp decline to 44,000 tonnes in 1977. Mackerel shows a history similar to herring. Whilst some species are in a period of decline, others have increased, for example sandeels (mainly Ammodytes marinus), the catch of which has greatly increased since 1965 (130 thousand tonnes) reaching 786 thousand tonnes in 1977. Similarly, the catch of Norway pout varied in the period 1962-77, being 53 thousand tonnes in 1966 and 823 thousand tonnes in 1974 (ICES 'Bulletin Statistique' for the years 1947-77) (ICES, 1951-81).

Although the herring declined between 1947 and 1977 (from $69.1 \%$ in 1947 and $74.8 \%$ in 1948 to $1.7 \%$ in 1977), the percentage of plankton-feeders in the total catch of fish remained steady (average $69.8 \%$, range $51.6-77.3 \%$ ), apparently by virtue of the replacement of herring by other plankton-feeding fishes (from $1.6 \%$ in 1947 to $67.3 \%$ in 1977) (Table 4 , Fig. 2). It is therefore of considerable interest to find that, despite these and other changes in the total catch or the catches of individual species, the mean trophic level of the nominal catch showed almost no change from 1947 to 1977, varying only between 3.62 and 3.76 .

Generally speaking, the catch should approximately reflect the abundance in a well-exploited sea. Assuming that the trophic levels of the 34 species were similar during 1947-77, fishing does not appear to have upset the fundamental ecological balance of the North Sea. In other words, the influence of fishing has not yet surpassed the self-regulatory capacity of the North Sea ecosystem. 
Table 4. North Sea fish: mean trophic level of nominal catch, nominal total catch", and plankton feeders as \% of total catch during 1947-1977

\begin{tabular}{|c|c|c|c|c|c|}
\hline \multirow[t]{2}{*}{ Year } & \multirow{2}{*}{$\begin{array}{c}\text { Mean trophic level } \\
\text { of nominal catch }\end{array}$} & \multirow{2}{*}{$\begin{array}{l}\text { Nominal total } \\
\text { catch (tonnes) }\end{array}$} & \multicolumn{3}{|c|}{ Plankton feeders as $\%$ of total catch } \\
\hline & & & All species & Herring & Others \\
\hline 1947 & 3.68 & 1431061 & 70.7 & 69.1 & 1.6 \\
\hline 1948 & 3.64 & 1726524 & 77.1 & 74.8 & 2.4 \\
\hline 1949 & 3.65 & 1460944 & 75.7 & 72.4 & 3.3 \\
\hline 1950 & 3.64 & 1489777 & 77.2 & 74.3 & 2.8 \\
\hline 1951 & 3.64 & 1655838 & 77.3 & 73.7 & 3.7 \\
\hline 1952 & 3.65 & 1590943 & 75.7 & 72.0 & 3.7 \\
\hline 1953 & 3.64 & 1677671 & 76.3 & 72.2 & 4.0 \\
\hline 1954 & 3.65 & 1783586 & 76.9 & 72.7 & 4.1 \\
\hline 1955 & 3.64 & 1973448 & 77.3 & 71.5 & 5.8 \\
\hline 1956 & 3.64 & 1971920 & 76.8 & 69.2 & 7.6 \\
\hline 1957 & 3.68 & 1752539 & 71.1 & 59.8 & 11.3 \\
\hline 1958 & 3.71 & 1506256 & 66.3 & 53.4 & 12.9 \\
\hline 1959 & 3.68 & 1677000 & 70.6 & 53.9 & 16.7 \\
\hline 1960 & 3.67 & 1479337 & 69.9 & 53.5 & 16.5 \\
\hline 1961 & 3.70 & 1450900 & 66.3 & 50.6 & 15.7 \\
\hline 1962 & 3.62 & 1621683 & 74.1 & 44.4 & 29.7 \\
\hline 1963 & 3.64 & 1824794 & 72.1 & 47.3 & 24.8 \\
\hline 1964 & 3.68 & 1842527 & 65.3 & 46.5 & 18.8 \\
\hline 1965 & 3.68 & 2499462 & 69.0 & 51.9 & 17.1 \\
\hline 1966 & 3.69 & 2841482 & 66.8 & 37.6 & 29.2 \\
\hline 1967 & 3.65 & 2944329 & 73.8 & 27.9 & 45.8 \\
\hline 1968 & 3.66 & 3275535 & 73.0 & 26.0 & 47.0 \\
\hline 1969 & 3.74 & 3147632 & 55.7 & 23.1 & 32.7 \\
\hline 1970 & 3.76 & 3039113 & 51.6 & 24.7 & 26.9 \\
\hline 1971 & 3.73 & 2867992 & 60.7 & 22.5 & 38.2 \\
\hline 1972 & 3.73 & 2858888 & 60.8 & 21.2 & 39.7 \\
\hline 1973 & 3.69 & 2910990 & 66.0 & 20.6 & 45.4 \\
\hline 1974 & 3.65 & 3379222 & 68.7 & 9.7 & 59.1 \\
\hline 1975 & 3.62 & 3190710 & 70.8 & 9.0 & 61.8 \\
\hline 1976 & 3.70 & 2438713 & 60.1 & 5.0 & 55.1 \\
\hline 1977 & 3.63 & 2674831 & 68.9 & 1.7 & 67.3 \\
\hline Average & 3.67 & 2193085 & 69.8 & 45.6 & 24.2 \\
\hline
\end{tabular}

Acknowledgements. This work was carried out under the exchange agreement between the Royal Society and the Academia Sinica. I am indebted to Dr. D. J. Garrod and Dr. J. G. Shepherd who arranged my research work at the Fisheries Laboratory, Lowestoft, and to Professor Wu Hsien-wen who endorsed my nomination for participation in the exchange scheme. Sincere thanks are due to all persons who have assisted me with this work, in particular to Dr. D. H. Cushing, FRS, Mr. J. G. Pope and Mr. L. Birkett for guidance in this study; to Mr. L. Birkett and Mr. T. Wyatt for valuable comments on the manuscript; and to Mr. A. R. Margetts and Mrs. I. $R$. Gooch for assistance with the preparation of the text and illustrations.

\section{LITERATURE CITED}

Allen, J. A. (1960). On the biology of Crangon allmani Kinaham in Northumberland waters. J. mar. biol. Ass. U. K. 39: 481-508

Braber, L., de Groot, S. J. (1973). The food of five flatfish species (Pleuronectiformes) in the southern North Sea Neth. J. Sea Res. 6(1-2): 163-172

Bullen, G. E. (1912). Some notes upon the feeding habits of mackerel and certain clupeoids in the English Channel. J. mar. biol. Ass. U. K. 9: 394-403

Campbell, A. C. (1976). The seashore and shallow seas of Britain and Europe, Hamlyn, London

Daan, N. (1973). A quantitative analysis of the food intake of North Sea cod, Gadus morhua. Neth. J. Sea Res. 6(4): 479-517

Davis, C. C. (1955). The marine and freshwater plankton, Michigan State University Press, East Lansing, Michigan

Hardy, A. C. (1924). The food and feeding habits of the herring. Fishery Invest., Lond. (Ser. 2) 7(3): 1-53

Hartley, P. H. T. (1940). The Saltash tuck-net fishery and the ecology of some estuarine fishes. J. mar. biol. Ass. U. K. 24: $1-68$

Hynes, H. B. N. (1950). The food of freshwater sticklebacks (Gasterosteus aculeatus and Pygosteus pungitius), with a review of methods used in studies of the food of fishes. J. Anim. Ecol. 19: 36-58 
ICES - Bulletin Statistique, 32-63 (for the years 1947-78) $(1951-81)$

Kaestner, A. (1967). Invertebrate zoology, Vol. 1, Interscience Publishers, New York

Kaestner, A. (1970). Invertebrate zoology, Vol, 3, Interscience Publishers, New York

Last, J. M. (1978a). The food of four species of pleuronectiform larvae in the eastern English Channel and southern North Sea. Mar. Biol. 45: 359-368

Last, J. M. (1978b). The food of three species of gadoid larvae in the eastern English Channel and southern North Sea. Mar. Biol. 48: 377-386

Last, J. M. (1980). The food of twenty species of fish larvae in the west-central North Sea. Fish. Res. Tech. Rep., MAFF Direct. Fish. Res. Lowestoft (60): 1-44

Lebour, M. V. (1918). The food of post-larval fish. J. mar. biol. Ass. U. K. 11: 433-469

Lebour, M. V. (1919). The food of post-larval fish. J. mar. biol. Ass. U. K. 12: 22-47

Lebour, M. V. (1922). The food of plankton organisms. J. mar. biol. Ass. U. K. 12: 644-677

Lebour, M. V. (1924). The food of plankton organisms, II. J. mar. biol. Ass. U. K. 13: 70-92

Macer, C. T. (1966). Sand eels (Ammodytidae) in the southwestern North Sea; their biology and fishery. Fishery Invest., Lond. (Ser. 2) 24(6): 1-55

Macer, C. T (1977). Some aspects of the biology of the horse mackerel (Trachurus trachurus [L.]) in waters around Britain. J. Fish Biol, 10: 51-62

Marshall, S. M., Orr, A. P. (1972). The biology of a marine copepod, Springer-Verlag, Berlin

Oakley, S. G. (1978). Food, feeding behaviour and some aspects of the ecology of Nephrops norvegicus in the Irish Sea. Ph. D. thesis, University of Liverpool

Rae, B. B. (1956). The food and feeding habits of the lemon sole. Mar. Res. Scotl. 1956 (3): 1-32

Rae, B. B. (1963). The food of the megrim. Mar. Res. Scotl. 1963 (3): $1-23$

Rae, B. B. (1967). The food of cod in the North Sea and on west of Scotland grounds. Mar. Res. Scotl. 1967 (1): 1-68

Raitt, D. F. S., Adams, J. A. (1962). The food of Gadus esmarkii
Nilsson and a comparison with its planktonic environment. ICES Gadoid Committee, No. 80: 1-5 (mimeo)

Raymont, J. G. (1963). Plankton and productivity in the oceans, Pergamon Press, Oxford

Ryland, J. S. (1964). The feeding of plaice and sandeel larvae in the southern North Sea. J. mar biol. Ass. U. K. 44 : $343-364$

Savage, R. E. (1937). The food of North Sea herring 1930-34 Fishery Invest., Lond. (Ser. 2) 15(5): 1-60

Scott, T. (1902). Observations on the food of fishes. Rep. Fishery Bd Scotl. 20 (for 1901): 486-538

Shuvaev, Yu. D. (1977). Food habits of larval haddock in the North Sea. Trudy vses. nauchno-issled. Inst. morsk. ryb. Khoz. Okeanogr. 121: 88-92

Simpson, A. C. (1970). Synopsis of biological data on the shrimp Pandalus montagui Leach, 1814. FAO Fish. Rep. No. 57, Vol. 4: 1225-1249

Smith, W. R. (1889). On the food of fishes. Rep. Fishery Bd Scotl. 7 (for 1888): 222-258

Smith. W. R. (1890). On the food of fishes. Rep. Fishery Bd Scotl. 8 (for 1889): $230-256$

Steele, J. H. (1974). The structure of marine ecosystems, Blackwell, Oxford

Tiews, K. (1970). Synopsis of biological data on the common shrimp Crangon crangon (Linnaeus, 1758). FAO Fish. Rep. No. 57, Vol. 4: 1167-1224

Todd, R. A. (1905). Report on the food of fishes collected during 1903. Rep. N. Sea Fish. Invest. Comm. I (South Area), Pt. I: 53-160

Todd, R. A. (1907). Second report on the food of fishes (North Sea, 1904-5). Rep. N. Sea Fish. Invest. Comm. II (South Area), Pt. I: $53-160$

Wyatt, T. (1974). The feeding of plaice and sand-eel larvae in the Southern Bight in relation to the distribution of their food organisms. In: Blaxter, J. H. S. (ed.) The early life history of fish, Springer-Verlag, Berlin, pp. 245-251

Zilanov, V. K. (1966). Blue whiting. Annls biol., Copenh. 23: $119-121$

Zilanov, V. K. (1968). Some data on the biology of Micromesistius poutassou (Risso) in the north-west Atlantic. Rapp. P.-v. Réun. Cons. int. Explor. Mer 158: 116-121 